my mother spent twenty years in a mental hospital, where she died, while my father, who became a professor of science, lives a life of luxury retirement in Florida. Discourse doesn't tell us enough about men's privileged positions, it doesn't explain why and how certain discourses carry more weight, more cogency than others.

It seems to me that no one theory has yet adequately accounted for family violence. It needs to be broken down into smaller conceptual categories. Ironically, Gordon does do just this, and does it well, but then lumps them all together under the rubric of 'family violence'. Yet incest and wife-beating, child neglect and child-battering cannot necessarily be explained in similar ways. What is clear is that they need much more research and thought before any one theoretical paradigm can be used to explain them all. I suggest that what may be needed is a new paradigm altogether. Linda Gordon's book has made an excellent and pioneering start to this project.

\section{Diana Gittins}

\section{Unruly Practices: Power, Discourse and Gender in Contemporary Social \\ Theory}

\section{Nancy Fraser}

Polity Press in association with Basil

Blackwell: Oxford, 1989

ISBN 0745603912 , £8.95 Pbk; ISBN $0745603904 £ 27.50 \mathrm{Hbk}$

In her introduction to Unruly Practices, Nancy Fraser, the American philosopher and critical theorist, locates her work in relation to the state of American academia: 'It is fashionable nowadays to decry efforts to combine activism and academia. Neoconservatives tell us that to practice critique while employed by an education institution is a betrayal of professional standards. Conversely, some independent left-wing intellectuals insist that to join the professoriat is to betray the imperative of critique. Finally, many activists outside the academy doubt the commitment and reliability of academics who claim to be their allies and comrades in struggle' (1). These are issues also familiar to feminists outside America which often crystallize into questions of the accountability of feminist academics to the broader women's movement. Fraser's aim is to be a politically critical academic who recognizes that radicals in universities do 'find themselves subject to competing pressures and counter pressures ... do internalise several distinct and mutually incompatible sets of expectations'. A reading of Unruly Practices from outside the American academic context left me wondering about the possibilities and limits of politicized critical practice in the United States. Is it possible to cross the boundaries between academic criticism and activism outside higher education? How important are questions of style, accessibility and audience? Is it enough for a socialist feminist to write in ways that assume considerable prior knowledge on the part of readers and are taxing even for other academics? Certainly there must be a space for such work but what, ultimately, are its politics?

The essays collected in Unruly Practices were first published in various American journals between 1981 and 1988. Divided into three sections, the essays undertake a critical engagement with various aspects of contemporary social theory. Part one deals with crucial aspects of Foucault's work: his concept of power, the question of his 'conservatism' and his 'body language'. Readers who are already familiar with Foucault's texts will find these essays interesting, 
cogently argued and a useful contribution to the current debate on the critical and political potential of Foucauldian theory. Of particular interest is Fraser's consideration of Foucault's relationship to liberal norms of what is good and desirable and the question of how one distinguishes between acceptable and unacceptable forms of power. These issues are taken up in all three essays which also look at the status of modernity in Foucault's work and his 'rejection' of humanism.

Part two comprises two essays. They examine the relation between politics and deconstruction in the work of the French Derrideans and Richard Rorty's position in relation to romanticism and technocracy. Like the previous essays, these, too, assume a fair degree of prior knowledge. They are specialized, yet interesting. It is in Part Three that Fraser moves on to consider more directly aspects of gender in social theory. She analyzes the gender blindness of Habermas's 'socialtheoretical categorical framework' and looks at the gendered nature of definitions of need and social welfare provisions in the United States.

It will come as little surprise to those familiar with social theory and feminist critiques of the welfare state, whether in Britain or America, to learn that different sectors of the welfare state are gendered and that they position women and men differently. Fraser looks at the position of women both as recipients of welfare programmes and as paid and unpaid social-service workers. She highlights the counterfactual nature of the assumptions on which welfare provisions are based, pointing, for example, to how 'fewer than 15 per cent of US families conform to the normative ideal of domicile shared by a husband who is sole breadwinner, a wife who is full-time homemaker, and their offspring' (149). She argues that social insurance schemes which provide unemployment benefit position recipients as 'rights-bearers' - purchasing consumers who are receiving something for which they have paid. Other forms of welfare provision, which are directed primarily at women - relief programmes, food stamps, Medicaid and public-housing assistance - define their recipients as "beneficiaries of government largess" or "clients of public charity" and reinforce patriarchal structures (152). Following on from this, Fraser shows, in her final chapter, how definitions of needs are an important political issue for feminists.

Unruly Practices is a useful book for students of social theory. It will appeal to those interested in and familiar with the work of Foucault, Rorty and Habermas as well as readers concerned with the implications of social theory in public policy. The loosely connected series of essays are clearly written, dense and demanding. The final chapters on the politics of need-interpretation, which attempt to put theoretical insights into practice, are perhaps the most accessible. They clearly demonstrate that social theories do inform welfare practice and that critiques of gendering in social theory can throw light on how contemporary welfare practice might be challenged.

\section{Chris Weedon}

